\title{
MENUMBUHKAN KARAKTER KEBANGSAAN MELALUI PENDEKATAN HUMANIS BERBASIS KEARIFAN LOKAL PADA ANAK USIA DINI
}

\author{
Mardawani, Agusta Kurniati \\ STKIP Persada Khatulistiwa Sintang \\ mardawani113@yahoo.co.id, agusta.kurniati@gmail.com
}

\begin{abstract}
Lately Indonesia is going through a moral crisiscaused the weakness of the education character that had been obtained. At the other side, the fragility of the character of a nation,can occur caused by the fragility of education character in the school, in the family and in the society. One of the causes of the character of nationality has not been fully ingrained in society life that is the approach that measures all the action based on personal and common interests so that is not a strange thing to ignoring the humanity. The relevant to current public situation is humanist approach based on local knowledge where approach which puts forward humanity values but still on the inheritance values and cultural traditions local. In general the purpose of this program (dedication to community)providing information about an effort to bring the character nationality based on humanist approach in the local wisdom in early childhood. Devotion to the community activities this was done in the training method. This training been implemented collaboration between teams lecturer training with student participants of practical work and student study service in Melayang Sari village through three stages those are:the training tutor, the implementation stage and the reporting and evaluation. As for the result of the training was give the briefingfor early childhood about various competence of the value and moral of local wisdom, directed in the case of ownership the effective use sensibility the ability and the potency of their lives and of the opportunities that prevail in the environment so the children have good skills which is estuary the application of competences who owned the participants through process of training character education humanist based on the local knowledge of sixteen types of the values.
\end{abstract}

Keywords: nationality character, humanist approach, local wisdom

\begin{abstract}
Abstrak: Belakangan ini bangsa Indonesia sedang mengalami krisis moral yang disebabkan lemahnya pendidikan karaker yang diterima. Disisi lain, rapuhnya karakter suatu bangsa, dapat terjadi disebabkan oleh rapuhnya pendidikan karakter di bangku sekolah dikeluarga, dan di masyarakat. Salah satu penyebab karakter kebangsaan belum sepenuhnya mendarah daging dalam kedupan masyarakat terletak pada pola pendekatan yang mengukur segela tindakan berdasarkan kepentingan pribadi dan sekelompok orang sehingga tak jarang mengabaikan sisi kemanusiaan. Pola yang relevan dengan situasi masyarakat saat ini adalah pola pendekatan humanis manusia yang berbasis kearifan lokal dimana pendekatan yang mengedepankan nilai-nilai kemanusiaan namun tetap pada pewarisan nilai-niali tradisi dan budaya setempat. Secara umum tujuan kegiatan PKM ini memberikan penyuluhan tentang Upaya menumbuhkan Karakter Kebangsaan melalui Pendekatan Humanis Berbasis Kearifan Lokal pada Anak Usia Dini. Kegiatan Pengabdian kepada Masyarakat ini dilakukan dengan metode pelatihan. Pelatihan ini dilaksanakan dengan kolaborasi antara tim dosen pelatihan bersama mahasiswa peserta PPL \& KKM di desa Melayang Sari melalui 3 tahapan diantaranya: tahap pelatihan tutor, tahap pelaksanaan serta tahap pelaporan dan evaluasi. Adapun hasil dari kegiatan pelatihan ini adalah memberi pembekalan bagi anak usia dini tentang berbagai kompetensi tentang nilai dan moral dari kearifan lokal, diarahkan pada kepemilikan kepekaan kemampuan dalam mendayagunakan dan mengembangkan potensi diri dan peluang yang ada dilingkungan sekitar agar anak memiliki melakukan keterampilan-keterampilan baik, yang merupakan muara penerapan kompetensi-kompetensi yang telah dimiliki para peserta melalui proses pelatihan pendidikan karakter melalui pendekatan humanis berbasis kearifan lokal yang berupa 16 jenis nilai.
\end{abstract}

Kata Kunci: Karakter Kebangsaan, Pendekatan Humanis, Kearifan Lokal 


\section{PENDAHULUAN}

Saat ini bangsa Indonesia sedang mengalami krisis moral. Pendidikan karakter bangsa yang sudah diupayakan dengan berbagai bentuk, hingga saat ini belum terlaksana dengan optimal. Disisi lain, rapuhnya karakter suatu bangsa, dapat terjadi disebabkan oleh rapuhnya pendidikan karakter di bangku sekolah dikeluarga, dan di masyarakat. Hal ini tercermin dari kesenjangan sosial, ekonomi, politik yang masih besar, kerusakan lingkungan yang terjadi di berbagai pelosok negeri dan masih terjadinya ketidakadilan hukum, pergaulan bebas dan pornografi yang terjadi di kalangan remaja, kekerasan dan kerusuhan, korupsi yang akhirnya merambah pada semua sektor kehidupan masyarakat. Bisa kita lihat pada saat ini banyak dijumpai tindakan anarkis, konflik social, penuturan bahasa yang buruk dan tidak santun, serta ketidaktaatan berlalu lintas. Masyarakat Indonesia yang terbiasa santun dalam berperilaku, melaksanakan musyawarah mufakat dalam menyelesaikanmasalah, mempunyai kearifan lokal yang kaya dengan pluralitas, serta bersikap toleran dan gotong royong mulai cenderung berubah menjadi saling mengalahkan dan berperilaku tidak jujur. Semua itu terjadi disebabkan oleh ketidakpastian jati diri dan karakter bangsa yang bermuara pada disorientasi dan belum dihayatinya nilai-nilai kearifan lokal sebagai bagian dari budaya bangsa.

Pancasila sebagai filosofi dan ideologi bangsa, keterbatasan perangkat kebijakan terpadu dalam mewujudkan nilai-nilai esensi Pancasila, bergesernya nilai etika dalam kehidupan berbangsa dan bernegara, memudarnya kesadaran terhadap nilai-nilai budaya bangsa dan ancaman disintegrasi bangsa, serta melemahnya

kemandirian bangsa.Memperhatikan situasi dan kondisi karakter bangsa yang memprihatinkan tersebut, pemerintah mengambil inisiatif untuk memprioritaskan pembangunan karakter bangsa. Pembangunan karakter bangsa seharusnya menjadi arus utama pembangunan nasional. Artinya, setiap upaya pembangunan harus selalu dipikirkan keterkaitan dan dampaknya terhadap pengembangan karakter. Hal itu sejalan dengan misi pembangunan nasional yang memposisikan pendidikan karakter sebagai misi pertama dari delapan misi guna mewujudkanvisi pembangunan nasional, sebagaimana tercantum dalam Rencana Pembangunan Jangka Panjang Nasional Tahun 2005 - 2025 (UndangUndang Republik Indonesia Nomor 17 Tahun 2007), yaitu terwujudnya karakter 
bangsayang tangguh, kompetitif, berakhlak mulia, dan bermoral berdasarkanPancasila, yang dicirikan dengan watak dan perilaku manusia dan masyarakat Indonesia yang beragam, beriman dan bertakwa kepada Tuhan Yang MahaEsa, berbudi luhur, bertoleran, bergotongroyong, berjiwa patriotik, berkembangdinamis, dan berorientasikan kepada IPTEK.

Karakter merupakan hal sangat esensial dalam berbangsa dan bernegara, hilangnya karakter akan menyebabkan hilangnya generasi penerus bangsa yang bermartabat, maka dapat dikatakan bahwa karakter berperan sebagai "kemudi" dan kekuatan sehingga bangsa ini tidak terombang-ambing. Karakter tidak datang dengan sendirinya, tetapi harus dibangun dan dibentuk untuk menjadi bangsa yang bermartabat. Selanjutnya, pembangunan karakter bangsa akan mengerucut pada tiga tataran besar, yaitu menumbuhkan dan memperkuat jati diri bangsa, menjaga keutuhan Negara Kesatuan Republik Indonesia (NKRI), membentuk manusia dan masyarakat Indonesia yang berakhlak mulia danbangsa yang bermartabat. Dalam rangka meningkatkan pembangunan karakter yang berhasil guna,diperlukan upaya-upaya nyata antara lain penyusunan desain pembangunan karakter secara nasional, penyusunan rencana aksi nasional secara terpadu, Pencanangan pembangunan karakter bangsa oleh Presiden RepublikIndonesia sebagai tonggak dimulainya revitalisasi pembangunan karakterbangsa, serta implementasi pembangunan karakter oleh semua komponenbangsa dan aktualisasi nilai-nilai karakter secara nyata dalam kehidupanberbangsa dan bernegara.

Salah satu penyebab karakter kebangsaan belum sepenuhnya mendarah daging dalam kedupan masyarakat terletak pada pola pendekatan yang mengukur segela tindakan berdasarkan kepentingan pribadi dan sekelompok orang sehingga tak jarang mengabaikan sisi kemanusiaan. Untuk itu pola pendekatan pada masyarakat sangat menentukan terbentuknya karakter kebangsaan. Pola yang relevan dengan situasi masyarakat saat ini adalah pola pendekatan humanis manusia yang berbasis kearifan lokal dimana pendekatan yang mengedepankan nilai-nilai kemanusiaan namun tetap pada pewarisan nilai-niali tradisi dan budaya setempat. Berdasarkan informasi awal yang diperoleh di Kecamatan Sungai Tebelian khususnya di Desa Melayang Sari bahwa karakter kebangsaan belum sepenuhnya menjadi bagian dalam kehidupan bermasyarakat. Hal ini terindikasi dari masih terjadinya ucapan, 
sikap, dan perilaku sehari-hari anak di masyarakat yang belum menunjukkan karakter. Masih berkembangnya pola berpikir yang sempit, bertindak untuk kepentingan pribadi dan golongan, dan kurangnya wawasan berkaitan dengan kebangsaan. Adapun yang menjadi fokus utama dari kegiatan PKM ini adalah menumbuhkan Karakter Kebangsaan melalui Pendektan Humanis Berbasis Kearifan Lokal sejak usia Dini, diharapkan seja anak-anak masih usia dini telah mulai dari lingkungan keluarga nilai-nilai tentang Karakter Kebangsaan sudah ditamankan dilanjutkan oleh pedidikan formal dan lingkungan masyarakat.

\section{METODE PELAKSANAAN}

Kegiatan Pengabdian kepada Masyarakat ini dilakukan dengan metode pelatihan. Pelatihan ini dilaksanakan dengan kolaborasi antara tim dosen pelatihan dengan mahasiswa peserta PPL \& KKM di desa Melayang Sari. Dalam pelaksanaannya program ini direncanakan dilaksanakan melalui 3 langkah/tahapan kegiatan sebagai berikut:

1) Tahap Pelatihan Tutor (mahasiswa PPL-KKM)

Pada tahapan ini tim dosen PKM melakukan Tim dosen melaksanakan pelatihan kepada mahasiswa kolaborasi dengan langkah-langkah sebagai berikut: Kelompok PPL-KKM yang terdiri dari 12 orang dibagi menjadi 3 kelompok.

Masing-masing kelompok diberikan pelatihan oleh tim dosen tentang pengetahuan secara teoritis dan teknis guna persiapan pelaksana lapangan. Kegiatan ini dilaksanakan selama $3 \mathrm{x}$ dalam waktu 1 bulan.

2) Tahap Pelaksanaan

Tim PKM melaksanakan pelatihan terhadap subjek (anak usia dini) yang ada di desa Melayang Sari. Pada tahapan ini kegiatan terdiri dari 3 tahapan yakni: tahap 1). Masa reorientasi 2 minggu pertama untuk pendataan dan pembagian kelompok. Masing-masing kelompok dibina oleh 4 orang mahasiswa pendamping; 2). Pelaksanaan pelatihan dilakukan dengan 3 bagian: 1). Tahap Pendataan; adalah tahapan dimana tim melakukan pendataan secara riil di desa Melayang Sari berapa jumlah anak usia dini, dan mensosialisasikan maksud dan tujuan dari pendataan tersebut. 2). Tahap Perencanaan; adalah tahap pemantapan rencana pelaksanaan kegiatan pelatihan, pada tahapan ini 
tim dan peserta menyepakati teknis dan tempat pelaksanaan pelatihan termasuk mengenai kepastian waktu dan lamanya kegiatan.3). Tahap Pelaksanaan; pada tahapan ini dilaksanakannya kegiatan pelatihan dengan: (1). Membekali peserta pelatihan untuk memiliki pengetahuan, kemauan dan keterampilan dimaksudkan agar peserta memahami secara benar dan menyeluruh tentang potensi dan peluang yang ada dilingkungan (memanfaatkan kearifan lokal). 2). Membekali peserta tentang berbagai kompetensi tentang nilai dan moral dari kearifan lokal, diarahkan pada kepemilikan kepekaan kemampuan dalam mendayagunakan dan mengembangkan potensi diri dan peluang yang ada dilingkungan sekitar. 3). Membiasakan peserta untuk selalu melakukan keterampilan-keterampilan baik, yang merupakan muara penerapan kompetensi-kompetensi yang telah dimiliki para peserta melalui proses pembelajaran pada tahapan sebelumnya.

3) Tahap Evaluasi dan Pelaporan

Tahap evaluasi merupakan tahap evaluasi hasil pelatihan yang dilaksanakan melalui tes perkembangan peserta latihan. Hasil dari proses kegiatan pelatihan selama \pm 3 bulan kemudian dilaporkan dalam bentuk laporan tertulis.

\section{HASIL DAN PEMBAHASAN}

Kegiatan Pengabdian kepada Masyarakat ini dilakukan dengan metode pelatihan. Pelatihan ini dilaksanakan secara kolaborasi antara tim dosen pelatihan dengan mahasiswa peserta PPL \& KKM di desa Melayang Sari. Dalam pelaksanaannya program ini sesuai dengan apa yang telah direncanakan dilaksanakan melalui 3 langkah/tahapan kegiatan sebagai berikut:

1) Tahap Pelatihan Tutor (mahasiswa PPL-KKM)

Tahapan ini dilaksanakan pada minggu pertama dan kedua bulan Oktober tahun 2017. Pada tahapan ini tim dosen PKM melakukan melaksanakan pelatihan kepada mahasiswa kolaborasi dengan langkah-langkah sebagai berikut: Kelompok PPL-KKM yang terdiri dari 12 orang dibagi menjadi 3 kelompok. Jadi masing-masing kelompok didampingi oleh 4 orang tutor. Selama proses kegiatan pelatihan, kelompok secara teknis 
dibagi lagi menjadi sehingga hanya

5 pesertra dengan 2 pendamping.

Hal ini dilaksanakan guna mengefektifkan kegiatan. Masingmasing kelompok diberikan pelatihan oleh tim dosen tentang pengetahuan secara teoritis dan teknis guna persiapan pelaksana lapangan. Kegiatan ini dilaksanakan selama 3 x dalam waktu 1 bulan, dengan kegiatan pertemuan pertama dilaksanakan oleh tim pelatih dan mahasiswa perwakilan kelompok 4 orang, pertemuan kedua dan ketiga bersama semua anggota tim pelatih baik dari dosen maupun mahasiswa.

2) Tahap Pelaksanaan

Tim PKM melaksanakan pelatihan terhadap subjek (anak usia dini) yang ada di desa Melayang Sari. Pada tahapan ini kegiatan terdiri dari 3 tahapan yakni: tahap 1). Masa reorientasi 2 minggu pertama untuk pendataan dan pembagian kelompok. Masing-masing kelompok dibina oleh 4 orang mahasiswa pendamping; 2). Pelaksanaan pelatihan dilakukan dengan 3 bagian: 1). Tahap Pendataan; adalah tahapan dimana tim melakukan pendataan secara riil di desa Melayang Sari berapa jumlah anak usia dini, dan mensosialisasikan maksud dan tujuan dari pendataan tersebut. 2). Tahap Perencanaan; adalah tahap pemantapan rencana pelaksanaan kegiatan pelatihan, pada tahapan ini tim dan peserta menyepakati teknis dan tempat pelaksanaan pelatihan termasuk mengenai kepastian waktu dan lamanya kegiatan.3). Tahap Pelaksanaan; pada tahapan ini dilaksanakannya kegiatan pelatihan dengan: (1). Membekali peserta pelatihan untuk memiliki pengetahuan, kemauan dan keterampilan dimaksudkan agar peserta memahami secara benar dan menyeluruh tentang potensi dan peluang yang ada dilingkungan (memanfaatkan kearifan lokal). 2). Membekali peserta tentang berbagai kompetensi tentang nilai dan moral dari kearifan lokal, diarahkan pada kepemilikan kepekaan kemampuan dalam mendayagunakan dan mengembangkan potensi diri dan peluang yang ada dilingkungan sekitar. 3). Membiasakan peserta untuk selalu melakukan keterampilan-keterampilan baik, 
yang merupakan muara penerapan kompetensi-kompetensi yang telah dimiliki para peserta melalui proses pembelajaran pada tahapan sebelumnya.

Jumlah anak usia dini yang terlibat dalam kegiatan pelatihan ini sebanyak 30, namun sesungguhnya terdapat lebih dari 30 orang, akan tetapi berdasarkan hasil pendataan bahwa ada diantara anak-anak usia dini di desa Melayang Sari yang rumahnya agak jauh dari tempat pelatihan sehingga sulit mengikuti pelatihan secara rutin. Dengan demikian maka masing-masing kelompok yang terdiri dari 30 orang peserta didampingi oleh 4 orang pelatih yang berasal dari mahasiswa.

\section{3) Tahap Evaluasi dan Pelaporan}

Tahap evaluasi merupakan tahap evaluasi hasil pelatihan yang dilaksanakan melalui tes perkembangan peserta latihan. Hasil dari proses kegiatan pelatihan selama \pm 3 bulan kemudian dilaporkan dalam bentuk laporan tertulis. Dari evaluasi yang diadakan oleh tim pelatih ternyata hampir $75 \%$ peserta pelatihan memiliki kemampuan yang meningkat setelah mengikuti serangkaian kegiatan yang dilakukan. Dengan perkataan lain bahwa kegiatan pelatihan yang dilaksanakan dapat menumbuhkan karakter kebangsaan melalui pendekatan humanis berbasis kearifan lokal pada anak usia dini di Desa Melayangsari

\section{SIMPULAN}

Berdasarkan hasil pelaksnaan kegiatan PKM yang telah dilaksanakan di Desa Melayang Sari berkaitan dengan judul "menumbuhkan karakter kebangsaan melalui pendekatan humanis berbasis kearifan lokal pada anak usia dini" dapat disimpulkan hal-hal sebagai berikut:

1. Salah satu cara membekali anak usia dini agar memiliki pengetahuan, kemauan dan keterampilan secara benar dan menyeluruh tentang potensi dan peluang yang ada dilingkungan dengan memanfaatkan kearifan lokal adalah dengan memberikan pengajaran / pendidikan yang humanis oleh lingkungan, baik orang tua, sekolah maupun masyarakat.

2. Membekali anak usia dini tentang berbagai kompetensi tentang nilai dan moral dari kearifan lokal, diarahkan pada kepemilikan kepekaan kemampuan dalam mendayagunakan dan mengembangkan potensi diri dan peluang yang ada dilingkungan sekitar melalui pengajaran akan 16 nilai dasar 
sebagai pondasi karakter bangsa

Indonesia.

3. Penting membiasakan anak usia dini untuk selalu melakukan keterampilanketerampilan baik, yang merupakan muara penerapan kompetensikompetensi yang telah dimiliki para peserta melalui proses pelatihan pendidikan karakter melalui pendekatan humanis berbasis kearifan lokal.

\section{DAFTAR RUJUKAN}

Implementasi Kebijakan Nasional Pembangunan Karakter Bangsa MelaluiPendidikan Karakter, PPS Universitas Terbuka, Jakarta, 2010

Kemendiknas RI, Disain Induk Pendidikan Karakter, Jakarta, 2010

Lickona, T., Schaps, E., \& Lewis, C. (1995) prinsip-prinsip Sebelas pendidikan karakter yang efektif Washington, DC:.. Karakter Kemitraan Pendidikan.

Nugroho Triatmojo, Pendidikan Kewarganegaraan, Karakter Bangsa, http://nugi45blog.com, diakses tanggal 06 Mei 2012

Udin Saripudin Winataputra, Jati diri Pendidikan Kewarganegaraan sebagai wahana Pendidikan Demokrasi, Program Pascasarjana Universitas Pendidikan Indonesia (Disertasi), Bandung,2000. 